\title{
KAJIAN PEMBERIAN SISA PENGGILINGAN PADI DAN PUPUK ORGANIK CAIR TERHADAP PERTUMBUHAN VEGETATIF TANAMAN SAWI HIJAU (Brassica juncea L.)
}

\author{
Rahmadina $^{1}$, Ulfayani Mayasari ${ }^{2}$ \\ 1,2Program Studi Biologi, Fakultas Sains dan Teknologi, Universitas Islam Negeri Sumatera Utara \\ *Corresponding author: rahmadina@uinsu.ac.id
}

\begin{abstract}
Green mustard plant (Brassica juncea var. Parachinensis L.) is a plant that has benefits as a source of vitamins, minerals and high nutritional value. The purpose of this research was to determine the effect of rice grinder concentration and liquid organic fertilizer on vegetative growth of mustard greens (Brassica juncea L.). The effect of a mixture of giving POC with plant growth and the effect of a combination of POC and a mixture of planting media on growth mustard plant was found to. In this case the research was conducted on February to May 2020, and location at Medan Johor District, Medan City. It was used a research method in factorial randomized design consisting of 2 factors and 3 replications. The final results of this research indicated that the POC concentration did not show any significant effect on plant height, number of leaves, leaf length, leaf width, leaf area, wet weight, and chlorophyll of mustard plants. But, visually the highest results were obtained at P2 treatment (30 cc / L water) followed by P1 (15 cc / L water) and the lowest in P0 treatment (without POC), the mixture of planting media showed a very significant effect on plant height at ages 7 and 14 HST and had no significant effect on all other observing variables. The highest yield was obtained in the treatment of M0 (Top Soil Soil) followed by M1 (Top Soil and Rice Husk Mixture) and M3 (Top Soil and Rice bran Mixture) and the lowest in M2 (Top Soil and Bran Soil) mixture, POC and the planting media mixture showed a very significant effect on the plant height variable at 14 HST and the amount of chlorophyll at harvest and had no significant effect on other variables. The best results were obtained on M3 P2 (Top Soil and Rice bran Mixture; P2 (POC concentration of $30 \mathrm{cc} / \mathrm{L}$ water).
\end{abstract}

Keywords: Brassica juncea, POC, liquid organic fertilizer, rice

\section{PENDAHULUAN}

Tanaman sawi hijau dapat menghasilkan produksi yang bervariasi pada beberapa negara di Asia. Salah satu penghasil Sawi tertinggi di Asia ialah negara Philipina dengan jumlah 25.500 ton, sedangkan negara kedua yaitu Malaysia dengan jumlah rata-rata 50.000 ton sayuran sawi hijau, bahkan China dapat menghasilkan $30-40 \%$ sayuran sawi hijau pertahunnya (Tay dan Toxofeus, 1994).

Tanaman sawi hijau (Brassica juncea var. Parachinensis L.) ini termasuk sayuran yang tidak asing lagi, mudah ditemukan di setiap pasar. Hal ini dikarenakan jenis sayuran ini memiliki harga yang terjangkau dan banyak manfaatnya serta memiliki sumber vitamin dan mineral yang bernilai tinggi. Setiap $100 \mathrm{~g}$ sayuran dalam bentuk yang segar memiliki kandungan $93 \mathrm{~g}$ air, 1,7 g protein, 0,2 g lemak, 3,1 g karbohidrat, dan 0,7 g serat pangan. Ada juga tanaman sayuran jenis sawi berupa Pak Choi yang memiliki sumber vitamin dan mineral yang baik dengan rincian 53 gr vitamin C, 2,3 mg $\beta$-karoten, 102 mg Ca, 46 mg P, dan 2,6 mg Fe dalam $100 \mathrm{~g}$ bobot segar (Tay dan Toxofeus, 1994).

Tanaman sawi merupakan jenis tanaman yang memiliki daun panjang, halus, tidak berbulu, tidak berkrop, berakar serabut yang tumbuh dan berkembang secara menyebar, dan perakarannya sangat dangkal pada kedalaman $5 \mathrm{~cm}$. Perakaran tanaman sawi dapat tumbuh dan berkembang dengan baik pada tanah yang gembur, subur, dan mudah menyerap air. Tanaman sawi memiliki batang pendek yang berwarna keputih- 
putihan dengan ukuran panjang $1,5 \mathrm{~cm}$ dan diameter 3,5 cm (Mandha, 2010).

Tanaman sawi hijau dapat hidup dalam kondisi lingkungan yang sesuai bagi pertumbuhannya sehingga dapat memberikan hasil panen yang tinggi dan menunjang usaha petani. Hal ini dikarenakan kecocokan keadaan lingkungan (iklim dan tanah) sangat menunjang produktifitas tanaman saat berproduksi. Pada saat ini masih banyak ditemukan petani yang mengalami kegagalan panen karena kurang memperhatikan keadaan lingkungan lokasi penanaman (Yudharta, 2010).

Salah satu penghasil produksi tanaman sawi hijau yang ada di Sumatera Utara beberapa tahun belakangan ini mengalami penurunan. Menurut Badan Pusat Statistik Sumatera Utara, produksi sawi mulai tahun 2005 sampai 2009 mengalami penurunan dengan rata-rata tiap tahun dimulai pada tahun 2005 produksinya sekitar 79.850 ton/ha, sedangkan tahun 2009 hasil produksi rata-rata 63.911 ton/ha. Kendala ini terjadi karena adanya tingkat pengurangan luas area lahan pertanian dan banyaknya petani sawi yang beralih pekerjaan ke bidang lain.

Produksi tanaman sawi dapat ditingkatkan melalui proses pemupukan. Pemupukan dapat dilakukan melalui tanah, pupuk alami dan pupuk buatan. Berdasarkan proses pembuatannya pupuk terdiri dari dua sumber yaitu pupuk organik dan pupuk anorganik. Pupuk Organik pembuatannya berasal dari proses alami dan pupuk anorganik pembuatannya melalui proses pabrikan.

Pupuk organik memiliki beberapa kandungan yang utama seperti kadar unsur hara yang tinggi, daya kemampua menyerap (bigroskopisitas) dan melepaskan air dari konsentrasi tinggi serta mudah larut dalam air sehingga mudah untuk diserap tanaman. Pupuk organik memiliki beberapa keistimewaan diantaranya sedikit pemakaiannya, praktis, hemat dalam pengangkutan, komposisi unsur hara lengkap, efek kerjanya cepat sehingga dapat berpengaruh pada tanaman. Dibalik keunggulannya, pupuk ini juga memiliki kekurangan yaitu tidak semua pupuk organik mengandung unsur hara lengkap, sehingga perlu ditambah dengan beberapa pupuk pelengkap mikro (Agromedia, 2007). Fosfat merupakan salah satu pupuk yang unsurnya tidak tersedia namun sangat diperlukan pada stadium permulaan untuk pertumbuhan tanaman. Pupuk fosfat dianjurkan digunakan sebagai pupuk dasar pada waktu tanam atau pengolahan tanah sebelum tanaman diberikan untuk ditanam (Hakim dkk., 1986).

Disamping kondisi unsur hara yang sangat dibutuhkan, kondisi tanah juga harus diperhatikan. Kondisi tanah yang cocok untuk tanaman sawi yaitu kondisi tanah yang gembur, yang banyak mengandung humus, subur, serta pembuangan airnya baik. Kondisi tanah yang baik harus memiliki derajat kemasaman $(\mathrm{pH})$ tanah yang optimum untuk pertumbuhannya yaitu berada diantara $\mathrm{pH} 6$ sampai pH 7 (Margiyanto, 2010).

Pupuk organik cair ialah serangkaian kumpulan pupuk yang berbentuk cair. Pupuk tersebut mudah untuk digunakan sehingga sangat berguna untuk semua tanaman, termasuk pembenihan, tumbuhan kecil, tanaman buah-buahan dan tanaman besar lainnya. Pupuk cair dapat dibuat dalam bentuk larutan yang memiliki tingkat konsentrasi yang tinggi sehingga perlu campuran larutan air dalam pemakaiannya. Pupuk dapat disimpan dengan kondisi yang dapat bertahan lama dan dapat digunakan untuk areal yang lebih luas. Pupuk dapat disimpan dengan catatan harus terlindung dari matahari dan hujan lebat (Misbahuddin, 2011).

Hadisuwito (2007) mengatakan bahwa pupuk organik cair merupakan jenis larutan yang berasal dari hasil pembusukan bahan-bahan organik dari sisa tanaman, kotoran hewan, dan manusia yang kandungan unsur haranya lebih dari satu unsur. Kelebihan dari pupuk organik cair ini yaitu secara cepat mengatasi defisiensi hara, tidak bermasalah dalam pencucian hara, dan mampu menyediakan hara yang cepat. Jika 
dibandingkan dengan pupuk anorganik cair, pupuk organik cair umumnya tidak merusak tanah dan tanaman walaupun digunakan sesering mungkin. Pupuk organik cair juga memiliki unsur Kalium yang berperan penting dalam setiap proses metabolisme tanaman, yaitu dalam sintesis asam amino, protein dari ion-ion ammonium, dan berperan dalam memelihara tekanan turgor dengan baik. Hal ini memungkinkan lancarnya proses-proses metabolisme untuk menjamin kesinambungan terjadinya pemanjangan sel dalam tubuh tanaman (Purwowidodo, 1992).

Pada proses penggilingan padi yang dilakukan ditempat penggilingan, hanya produksi beras yang dibutuhkan. Sementara itu, hasil sisanya berupa sekam, dedak, dan bekatul kurang begitu bermanfaat sehingga tidak dikelola secara optimal oleh petani. Adapun hasil produksi dari sisa penggilingan tersebut dapat bernilai jual tinggi jika dapat dikelola dengan baik. Hal ini dapat menambah nilai jual bagi pertanian maupun melalui pengembangan sistem agroindustri padi terpadu. Berdasarkan uraian diatas, penelitian ini dilakukan guna mengetahui bagaimana pertumbuhan dan produksi varietas sawi hijau (Brassica juncea var. Parachinensis L.) akibat pemberian sisa penggilingan padi dan Pupuk Organik Cair (POC).

\section{METODE PENELITIAN}

Penelitian ini dilakukan pada bulan Februari sampai dengan April 2020. Penelitian ini dilakukan pada lahan yang terletak di jalan Ekarasmi gg. Ekanusa Kecamatan Medan Johor-Kota Medan dengan ketinggian tempat \pm $30 \mathrm{~m}$ diatas permukaan laut. Adapun penggunaan bahan dalam penelitian ini adalah benih sawi hijau, hasil samping penggilingan padi yang diambil dari penggilingan padi kelompok Tani Subur di Kec. Sei Bulu Kab. Serdang Bedagai. Tanah top soil yang diambil dari Kec. Medan Johor Kota Medan, pupuk organik cair dan pestisida nabati yang diproduksi oleh petani di kelompok Tani Subur dan polybag ukuran $5 \mathrm{~kg}$ tanah. Alat yang digunakan yaitu handsprayer, cangkul, parang, gergaji, papan judul, papan plot, papan perlakuan, speed, dan alat-alat tulis.

Pada penelitian ini metode yang digunakan ialah Rancangan Acak Faktorial yang memiliki 2 faktor dan 3 ulangan. Faktor I. campuran hasil sampingan penggilingan padi dengan tanah top soil (M) yaitu M0 = Tanah Top Soil (5 kg) dan Sekam Padi (0 g), $\mathrm{M}_{1}=$ Campuran Tanah Top Soil (5 kg) dan Sekam Padi (25 g), M2 = Campuran Tanah Top Soil $(5 \mathrm{Kg})$ dan Dedak (25 g), M3 = Campuran Tanah Top Soil (5 Kg) dan Bekatul (25 g). Faktor II. Pupuk Organik Cair (P) yang terdiri dari tiga taraf yaitu: $\mathrm{P} 0=$ Tanpa Pemberian POC atau pemberian air $0 \mathrm{cc} / \mathrm{L}$ air, P1 = Pemberian POC $15 \mathrm{cc} / \mathrm{L}$ air, P2 = Pemberian POC $30 \mathrm{cc} / \mathrm{L}$ air, Jumlah Kombinasi 4 × $3=12$ kombinasi, Jumlah Ulangan $=3$ ulangan, jumlah polybag percobaan $=36$ polybag, Jarak antar polybag $=10 \mathrm{~cm}$.

Menurut Gomez dan Gomez (1996), penggunaan model linier dalam Rancangan Acak Kelompok (RAK) Faktorial pada penelitian ini ialah:

Dimana:

$$
\hat{Y} i j k=\mu+\varrho i+\alpha j+\beta k+(\alpha \beta) j k+\varepsilon i j k
$$

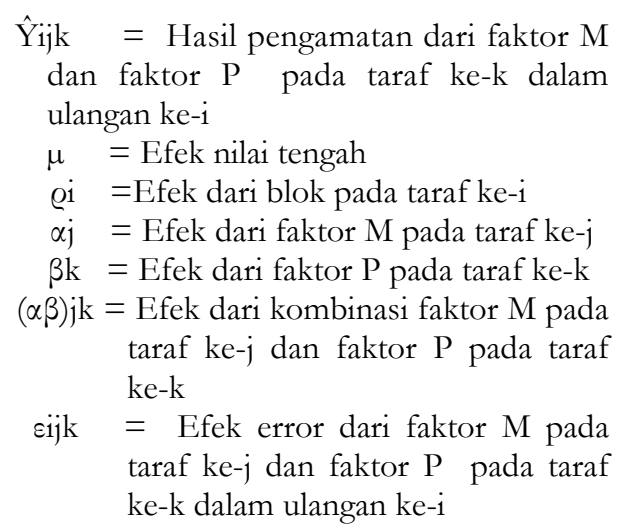

Penelitian ini dilakukan beberapa tahap proses pelaksanaan diantaranya melalui Persiapan Tanah, Penanaman Bibit, Pemupukan, Pemeliharaan Tanaman, Penyisipan, Pemberian Air, Penyiangan, Pengendalian Hama dan Penyakit, Panen, dan Peubah Amatan melalui Tinggi Tanaman (cm), Jumlah Daun (helai), Panjang Daun $(\mathrm{cm})$, Lebar Daun $(\mathrm{cm})$, Luas Daun $\left(\mathrm{cm}^{2}\right)$, Bobot Basah Tanaman, dan Jumlah Klorofil $\left(\mathrm{cm}^{2}\right)$ 
Analisis data yang dilakukan dalam penelitian ini menunjukkan perbedaan yang nyata dari perlakuan yang dicoba, kemudian dapat berlanjut dengan menggunakan metode uji Beda Rata Jujur (DMRT).

\section{HASIL DAN PEMBAHASAN}

Penelitian ini membahas tentang tiga hal yaitu sebagai berikut:

\section{Pengaruh Pemberian POC Cair terhadap Tanaman Sawi (Brassica juncea var. Parachinensis L.)}

(1). Tinggi Tanaman Sawi

Dalam penelitian ini diperoleh hasil bahwa perlakuan pemberian POC tidak menunjukkan pengaruh nyata terhadap tinggi tanaman sawi dari saat tanam sampai dengan saat panen. Rataan tinggi tanaman sawi akibat pemberian POC dari saat tanam sampai dengan saat panen disajikan pada Tabel 1.

Tabel 1. Rataan Tinggi Tanaman Sawi Akibat Pemberian POC $(\mathrm{cm})$

\begin{tabular}{cccccc}
\hline Perlakuan & \multicolumn{5}{c}{ Umur HST } \\
\cline { 2 - 6 } & $\begin{array}{c}\text { Saat } \\
\text { Tanam }\end{array}$ & $\mathbf{7}$ & $\mathbf{1 4}$ & $\mathbf{2 1}$ & $\begin{array}{c}\text { Saat } \\
\text { Panen }\end{array}$ \\
\hline P0 & 10,02 & 14,58 & 17,07 & 17,86 & 19,56 \\
P1 & 9,89 & 13,96 & 16,21 & 16,97 & 20,17 \\
P2 & 10,61 & 15,59 & 18,21 & 19,48 & 20,43 \\
\hline
\end{tabular}

Tabel 1 menunjukkan data secara statitstik bahwa perlakuan konsentrasi POC tidak memberikan pengaruh nyata, akan tetapi secara visual diperoleh bahwa tinggi tanaman tertinggi diperoleh pada perlakuan P2 (30 cc/L air) yang diikuti oleh perlakuan P1 (15 cc/L air) dan terendah pada P0 (tanpa pemberian POC).

(2). Jumlah Daun

Pada penelitian ini menghasilkan perlakuan pemberian POC yang tidak menunjukkan pengaruh nyata dengan jumlah daun tanaman sawi dari saat tanam sampai dengan saat panen. Rataan jumlah daun tanaman sawi akibat pemberian POC dari saat tanam sampai dengan saat panen yang tertera pada Tabel 2.
Tabel 2. Rataan Jumlah Daun Tanaman Sawi Akibat Pemberian POC (Helai)

\begin{tabular}{cccccc}
\hline Perlakuan & \multicolumn{5}{c}{ Umur HST } \\
\cline { 2 - 6 } & $\begin{array}{c}\text { Saat } \\
\text { Tanam }\end{array}$ & $\mathbf{7}$ & $\mathbf{1 4}$ & $\mathbf{2 1}$ & $\begin{array}{c}\text { Saat } \\
\text { Panen }\end{array}$ \\
\hline P0 & 4,92 & 5,33 & 5,00 & 6,33 & 7,58 \\
P1 & 4,08 & 4,00 & 4,75 & 6,67 & 8,33 \\
P2 & 4,08 & 4,33 & 4,42 & 5,58 & 6,75 \\
\hline
\end{tabular}

Tabel 2 menunjukkan meskipun secara statitstik perlakuan konsentrasi POC tidak memberikan pengaruh nyata, akan tetapi secara visual jumlah daun tanaman tertinggi diperoleh pada perlakuan P1 (15 cc/L air) diikuti oleh P2 (30 cc/L air) dan terendah pada perlakuan P0 (tanpa pemberian POC).

(3). Panjang Daun

Berdasarkan penelitian, diperoleh bahwa perlakuan pemberian POC tidak menunjukkan pengaruh nyata terhadap panjang daun tanaman sawi dari mulai tanam sampai dengan pemanenan. Rataan jumlah daun tanaman sawi akibat pemberian POC dapat terlihat pada Tabel 3.

Tabel 3. Rataan Panjang Daun Tanaman Sawi Akibat Pemberian POC (Helai)

\begin{tabular}{cccccc}
\hline Perlakuan & \multicolumn{5}{c}{ Umur HST } \\
\cline { 2 - 6 } & $\begin{array}{c}\text { Saat } \\
\text { Tanam }\end{array}$ & $\mathbf{7}$ & $\mathbf{1 4}$ & $\mathbf{2 1}$ & $\begin{array}{c}\text { Saat } \\
\text { Panen }\end{array}$ \\
\hline P0 & 6,08 & 7,32 & 7,80 & 8,42 & 9,68 \\
P1 & 5,98 & 6,90 & 7,97 & 8,86 & 9,10 \\
P2 & 6,59 & 7,88 & 9,00 & 9,79 & 10,43 \\
\hline
\end{tabular}

Tabel 3 menunjukkan meskipun secara statitstik perlakuan konsentrasi POC tidak memberikan pengaruh nyata, akan tetapi secara visual panjang daun tanaman tertinggi diperoleh pada perlakuan P2 $(30 \mathrm{cc} / \mathrm{L}$ air) diikuti oleh P0 (tanpa pemberian POC).dan terendah pada perlakuan P1 (15 cc/L air).

(4). Lebar Daun

Hasil analisis menunjukkan bahwa pemberian POC tidak menunjukkan pengaruh nyata terhadap jumlah lebar daun pada tanaman sawi mulai saat tanam sampai dengan saat panen. Rataan jumlah daun tanaman sawi akibat pemberian POC dari saat tanam sampai dengan saat panen dapat dilihat pada Tabel 4. 
Tabel 4. Rataan Lebar Daun Tanaman Sawi Akibat Pemberian POC (Helai)

\begin{tabular}{cccccc}
\hline Perlakuan & \multicolumn{5}{c}{ Umur HST } \\
\cline { 2 - 6 } & $\begin{array}{c}\text { Saat } \\
\text { Tanam }\end{array}$ & $\mathbf{7}$ & $\mathbf{1 4}$ & $\mathbf{2 1}$ & $\begin{array}{c}\text { Saat } \\
\text { Panen }\end{array}$ \\
\hline P0 & 4,06 & 4,58 & 4,84 & 5,04 & 5,32 \\
P1 & 4,08 & 4,56 & 5,11 & 4,75 & 5,50 \\
P2 & 4,19 & 5,06 & 5,66 & 6,03 & 5,78 \\
\hline
\end{tabular}

Tabel 4 menunjukkan meskipun secara statitstik perlakuan konsentrasi POC tidak memberikan pengaruh nyata, akan tetapi secara visual lebar daun tanaman tertinggi diperoleh pada perlakuan P2 (30 cc/L air) diikuti oleh P1 (15 cc/L air) dan terendah pada P0 (tanpa pemberian POC).

(5). Luas Daun, Berat Basah dan Jumlah Klorofil Saat Panen

Hasil analisis menunjukkan bahwa perlakuan pemberian POC tidak menunjukkan pengaruh nyata terhadap luas daun, berat basah dan jumlah klororil tanaman sawi saat panen. Rataan luas daun, berat basah dan jumlah klororil tanaman sawi saat panen akibat pemberian POC disajikan pada Tabel 5.

Tabel 5. Rataan Luas Daun, Berat Basah dan Jumlah Klorofil Tanaman Sawi Akibat Pemberian POC Pada Saat Panen

\begin{tabular}{cccc}
\hline Perlakuan & \multicolumn{3}{c}{ Saat Panen } \\
\cline { 2 - 4 } & $\begin{array}{c}\text { Luas } \\
\text { Daun } \\
\left(\mathbf{c m}^{\mathbf{2}}\right)\end{array}$ & $\begin{array}{c}\text { Berat } \\
\text { Basah } \\
\mathbf{( g )}\end{array}$ & Jlh Klorofil \\
\hline P0 & 80,27 & 6,56 & 30,65 \\
P1 & 84,87 & 6,73 & 29,81 \\
P2 & 96,56 & 7,66 & 29,51 \\
\hline
\end{tabular}

Tabel 5 menunjukkan meskipun secara statitstik perlakuan konsentrasi POC tidak memberikan pengaruh nyata, akan tetapi secara visual terhadap peubah luas daun dan berat basah hasil tertinggi diperoleh pada perlakuan P2 (30 cc/L air) diikuti oleh P1 (15 cc/L air) dan terendah pada perlakuan P0 (tanpa pemberian POC) sedangkan terhadap peubah jumlah klorofil hasil tertinggi diperoleh pada perlakuan P0 (tanpa pemberian POC diikuti oleh P1 (15 cc/L air) dan terendah pada perlakuan ) P2 (30 cc/L air).
Berdasarkan hasil penelitian melalui sidik ragam diperoleh hasil bahwa pemberian POC tidak menunjukkan pengaruh yang nyata terhadap semua peubah amatan pada tanaman sawi. Hal itu menunjukkan bahwa konsentrasi POC yang diberikan masih rendah sehingga tidak ada perbedaan antara yang diberikan POC dengan tanpa pemberian POC. Oleh karena itu, pemberian POC akan lebih baik bila dikombinasikan dengan pupuk kimia anorganik. Sutanto (2002) mengatakan bahwa penggunaan pupuk organik bukanlah sebagai pengganti peran dari pupuk kimia melainkan sebagai pelengkap fungsi dari pupuk kimia karena pupuk organik dan pupuk kimia akan lebih optimal dan lebih efisien digunakan jika bisa dimanfaatkan secara bersama-sama. Adapun penambahan pupuk organik ini dapat mengurangi dampak negative dari penggunaan pupuk kimia serta memperbaiki sifat fisik, biologi dan sifat dari kimia tanah secara bersamaan.

\section{Pengaruh Perlakuan Campuran Media Tanam} terhadap Tanaman Sawi

(1). Tinggi Tanaman Sawi

Hasil analisis menunjukkan bahwa perlakuan campuran media tanam menunjukkan pengaruh sangat nyata terhadap tinggi tanaman sawi pada umur 7 dan 14 HST dan berpengaruh tidak nyata pada saat tanam, umr 21 HST dan saat panen. Rataan tinggi tanaman sawi akibat perlakuan campuran media tanam saat tanam sampai dengan saat panen yang dapat dilihat pada Tabel 6 .

Tabel 6. Rataan Tinggi Tanaman Sawi Akibat Perlakuan Media Tanam (cm)

\begin{tabular}{cccccc}
\hline Perlakuan & \multicolumn{5}{c}{ Umur HST } \\
\cline { 2 - 6 } & $\begin{array}{c}\text { Saat } \\
\text { Tanam }\end{array}$ & $\mathbf{7}$ & $\mathbf{1 4}$ & $\mathbf{2 1}$ & $\begin{array}{c}\text { Saat } \\
\text { Panen }\end{array}$ \\
\hline M0 & 10,83 & 16,61 & 19,08 & 19,48 & 22,44 \\
M1 & 9,74 & 15,22 & 16,69 & 18,04 & 20,24 \\
M2 & 9,36 & 12,18 & 15,38 & 17,39 & 18,18 \\
M3 & 10,76 & 14,82 & 17,50 & 17,49 & 19,33 \\
\hline
\end{tabular}

Tabel 6. Hasil menunjukkan perlakuan campuran media tanam memberikan hasil tertinggi terhadap peubah tinggi tanaman diperoleh pada perlakuan M0 (Tanah Top Soil) diikuti oleh M1 
(Campuran Tanah Top Soil dan Sekam Padi) dan M3 (Campuran Tanah Top Soil dan Bekatul) serta terendah pada perlakuan M2 (Campuran Tanah Top Soil dan Dedak ).

(2) Jumlah Daun Tanaman Sawi

Hasil analisis menunjukkan bahwa perlakuan campuran media tanam tidak menunjukkan pengaruh nyata terhadap jumlah daun tanaman sawi dari saat tanam sampai dengan saat panen. Rataan jumlah daun tanaman sawi akibat perlakuan campuran media tanam dari saat tanam sampai dengan saat panen disajikan pada Tabel 7 .

Tabel 7. Rataan jumlah daun tanaman sawi akibat perlakuan media tanam (Helai)

\begin{tabular}{cccccc}
\hline Perlakuan & \multicolumn{5}{c}{ Umur HST } \\
\cline { 2 - 6 } & $\begin{array}{c}\text { Saat } \\
\text { Tanam }\end{array}$ & $\mathbf{7}$ & $\mathbf{1 4}$ & $\mathbf{2 1}$ & $\begin{array}{c}\text { Saat } \\
\text { Panen }\end{array}$ \\
\hline M0 & 4,67 & 5,11 & 5,22 & 6,78 & 7,67 \\
M1 & 4,44 & 4,44 & 5,11 & 6,56 & 7,78 \\
M2 & 4,33 & 4,44 & 4,0 & 5,22 & 7,44 \\
M3 & 4,33 & 3,89 & 4,56 & 6,22 & 7,33 \\
\hline
\end{tabular}

Tabel 7. Hasil menunjukkan bahwa perlakuan campuran media tanam tidak memberikan pengaruh yang nyata terhadap perlakuan yang dicobakan akan tetapi secara visual jumlah daun tertinggi tanaman sawi diperoleh pada perlakuan M1 (Campuran Tanah Top Soil dan Sekam Padi) diikuti oleh M0 (Tanah Top Soil) dan M2 (Campuran Tanah Top Soil dan Dedak) serta terendah pada perlakuan M3 (Campuran Tanah Top Soil dan Bekatul).

\section{(3). Panjang Daun Tanaman Sawi}

Berdasarkan hasil penelitian menunjukkan bahwa perlakuan campuran media tanam tidak menunjukkan pengaruh nyata terhadap panjang daun tanaman sawi dari saat tanam sampai dengan saat panen. Rataan panjang daun tanaman sawi akibat perlakuan campuran media tanam dari saat tanam sampai dengan saat panen disajikan pada Tabel 8.
Tabel 8. Rataan panjang daun tanaman sawi akibat perlakuan media tanam $(\mathrm{cm})$

\begin{tabular}{cccccc}
\hline Perlakuan & \multicolumn{5}{c}{ Umur HST } \\
\cline { 2 - 6 } & $\begin{array}{c}\text { Saat } \\
\text { Tanam }\end{array}$ & $\mathbf{7}$ & $\mathbf{1 4}$ & $\mathbf{2 1}$ & $\begin{array}{c}\text { Saat } \\
\text { Panen }\end{array}$ \\
\hline M0 & 6,09 & 8,02 & 8,92 & 9,86 & 10,34 \\
M1 & 5,97 & 7,53 & 8,12 & 9,42 & 9,98 \\
M2 & 6,00 & 6,57 & 7,88 & 8,60 & 9,07 \\
M3 & 6,51 & 7,34 & 8,10 & 8,21 & 9,56 \\
\hline
\end{tabular}

Tabel 8 menunjukkan meskipun perlakuan campuran media tanam tidak memberikan pengaruh yang nyata terhadap perlakuan yang dicobakan akan tetapi secara visual panjang daun tertinggi tanaman sawi diperoleh pada perlakuan $\mathrm{M}_{0}$ (Tanah Top Soil ) diikuti oleh M1 (Campuran Tanah Top Soil dan Sekam Padi) dan M3 (Campuran Tanah Top Soil dan Bekatul) serta terendah pada perlakuan M2 (Campuran Tanah Top Soil dan Dedak)

\section{(4). Lebar Daun Tanaman Sawi}

Hasil analisis menunjukkan bahwa perlakuan campuran media tanam tidak menunjukkan pengaruh nyata terhadap lebar daun tanaman sawi dari saat tanam sampai dengan saat panen. Rataan panjang daun tanaman sawi akibat perlakuan campuran media tanam dari saat tanam sampai dengan saat panen disajikan pada Tabel 9 .

Tabel 9. Rataan Lebar Daun Tanaman Sawi Akibat Perlakuan Media Tanam (cm)

\begin{tabular}{cccccc}
\hline Perlakuan & \multicolumn{5}{c}{ Umur HST } \\
\cline { 2 - 6 } & $\begin{array}{c}\text { Saat } \\
\text { Tanam }\end{array}$ & $\mathbf{7}$ & $\mathbf{1 4}$ & $\mathbf{2 1}$ & $\begin{array}{c}\text { Saat } \\
\text { Panen }\end{array}$ \\
\hline M0 & 4,07 & 4,93 & 5,37 & 5,31 & 6,29 \\
M1 & 4,03 & 4,87 & 5,57 & 5,66 & 5,67 \\
M2 & 4,13 & 4,28 & 4,87 & 5,14 & 5,13 \\
M3 & 4,20 & 4,84 & 5,01 & 4,99 & 5,03 \\
\hline
\end{tabular}

Tabel 9 menunjukkan meskipun perlakuan campuran media tanam tidak memberikan pengaruh yang nyata terhadap perlakuan yang dicobakan akan tetapi secara visual lebar daun tertinggi tanaman sawi diperoleh pada perlakuan M0 (Tanah Top Soil) diikuti oleh M1 (Campuran Tanah Top Soil dan Sekam Padi) dan M2 (Campuran Tanah Top Soil dan Dedak) serta terendah pada perlakuan M3 (Campuran Tanah Top Soil dan Bekatul). 
(5). Luas Daun, Berat Basah dan Jumlah Klorofil Saat Panen

Hasil analisis menunjukkan bahwa perlakuan campuran media tanam tidak menunjukkan pengaruh nyata terhadap luas daun, berat basah dan jumlah klorofil tanaman sawi pada saat panen. Rataan luas daun, berat basah dan jumlah klorofil tanaman sawi pada saat panen akibat perlakuan campuran media tanam disajikan pada Tabel 10 .

Tabel 10. Rataan Luas Daun, Berat Basah dan Jumlah Klorofil Tanaman Sawi Akibat Perlakuan Media Tanam Pada Saat Panen

\begin{tabular}{cccc}
\hline Perlakuan & \multicolumn{3}{c}{ Saat Panen } \\
\cline { 2 - 4 } & $\begin{array}{c}\text { Luas } \\
\text { Daun } \\
\mathbf{( \mathbf { c m } ^ { 2 } )}\end{array}$ & $\begin{array}{c}\text { Berat } \\
\text { Basah } \mathbf{( g )}\end{array}$ & Jlh Klorofil \\
\hline M0 & 100,75 & 7,95 & 28,93 \\
M1 & 89,16 & 7,07 & 29,86 \\
M2 & 72,88 & 5,78 & 29,61 \\
M3 & 86,14 & 7,15 & 31,56 \\
\hline
\end{tabular}

Tabel 10 menunjukkan meskipun perlakuan campuran media tanam tidak memberikan pengaruh yang nyata terhadap perlakuan yang dicobakan. Akan tetapi secara visual, luas daun dan berat basah memberikan hasil tertinggi yang sama yaitu pada perlakuan M0 (Tanah Top Soil) diikuti oleh M1 (Campuran Tanah Top Soil dan Sekam Padi) dan M3 (Campuran Tanah Top Soil dan Bekatul) serta terendah pada perlakuan M2 (Campuran Tanah Top Soil dan Dedak). Selanjutnya terhadap peubah jumlah klorofil hasil tertinggi diperoleh pada perlakuan M3 (Campuran Tanah Top Soil dan Bekatul) diikuti oleh M1 (Campuran Tanah Top Soil dan Sekam Padi) dan M2 (Campuran Tanah Top Soil dan Dedak) serta terendah pada perlakuan M0 (Tanah Top Soil).

Berdasarkan hasil data yang telah dilakukan melalui rekaman sidik ragam dihasilkan bahwa melalui pemberian campuran media dapat mempengaruhi tinggi tanaman yang sangat nyata pada umur 7 dan 14 HST dan tidak berpengaruh nyata terhadap semua peubah amatan lainnya pada tanaman sawi. Hal itu menunjukkan bahwa campuran media tanam telah memberikan pengaruh yang baik terhadap pertumbuhan tanaman sawi. Media tanam yang baik membuat unsur hara tetap tersedia, kelembaban terjamin dan drainase baik. Media tanaman yang dipakai harus dapat berfungsi sebagai penyedia air, zat hara dan oksigen serta tidak mengandung zat yang beracun bagi tanaman. Siswadi dan Yuwono (2013), mengatakan bahwa media tanaman yang sangat menentukan kemampuannya dalam menyerap air sehingga media yang tidak mampu menyerap air perlu penyiraman yang berulang-ulang agar dapat memberikan kelembaban media yang ideal bagi pertumbuhan dan perkembangan tanaman.

\section{Pengaruh Interaksi Pemberian POC dan Campuran Media Tanam terhadap Tanaman Sawi.}

Hasil analisis menunjukkan bahwa kombinasi POC dan campuran media tanam hanya menunjukkan pengaruh sangat nyata terhadap peubah tinggi tanaman umur 14 HST dan jumlah klorofil saat panen serta memberikan pengaruh tidak nyata terhadap peubah lainnya. Hasil terbaik didapat pada M3 P2 (Campuran Tanah Top Soil dan Bekatul ; P2 (konsentrasi POC $30 \mathrm{cc} / \mathrm{L}$ air).)

Berdasarkan data yang diperoleh bahwa kombinasi POC dan campuran media tanam memberikan pengaruh yang sangat nyata terhadap perubahan tinggi tanaman pada umur 14 HST dan jumlah klorofil saat panen serta memberikan pengaruh tidak nyata terhadap peubah lainnya. Hal itu menunjukkan bahwa kombinasi POC dan campuran media tanam telah memberikan hasil meskipun belum maksimal, sehingga perlu waktu yang lebih lama interaksi keduanya agar media campuran berupa hasil samping dari penggilingan padi baik sekam, dedak maupun bekatul dapat mengalami mineralisasi lebih sempurna dan POCnya perlu ditingkatkan konsentrasi serta interval pemberiannya.

\section{KESIMPULAN}

Jumlah konsentrasi POC tidak dapat menghasilkan pengaruh yang nyata terhadap tinggi tanaman, jumlah daun, panjang daun, lebar daun, luas daun, berat basah 
dan klorofil tanaman sawi, akan tetapi secara visual dapat memberikan hasil tertinggi pada perlakuan P2 (30 cc/L air) diikuti P1 (15 cc/L air) dan terendah pada P0 (POC tidak diberikan). Campuran media tanam menunjukkan pengaruh yang sangat nyata pada tinggi tanaman umur 7 dan 14 HST. Berdasarkan perolehan hasil tertinggi didapat pada perlakuan M0, M1, M3 dan M2. Kombinasi POC dan campuran media tanam menunjukkan pengaruh sangat nyata terhadap peubah tinggi tanaman umur 14 HST dan jumlah klorofil saat panen serta memberikan pengaruh tidak nyata terhadap peubah lainnya. Hasil terbaik ini didapat pada M3 P2 (Campuran Tanah Top Soil dan Bekatul ; P2 dengan konsentrasi POC $30 \mathrm{cc} / \mathrm{L}$ air).

\section{DAFTAR PUSTAKA}

Agromedia. 2007. Petunjuk Pemupukan. Agromedia Pustaka. Jakarta.

Gomez, K.A., dan A.A. Gomez. 1995. Prosedur Statistike untuk Penelitian Pertanian. (Terjemahan) E. Syamsudin dan J. S. Baharsjah. UI Press. Jakarta.

Hadisuwito, S. 2007. Membuat Pupuk Kompos Cair, Cetakan ketiga. Agromedia Pustaka. Jakarta.

Hakim, N., Nyakpa, M.Y., Lubis, A.M., Nugroho, S.G., Saul, M.R., Diha, M.A., Hong, G.B., dan H.H. Bailey. 1986. Dasar-Dasar Ilmu Tanah. Universitas Lampung. Bandar Lampung.
Margiyanto, E. 2010. Cahaya Tani http://Budidaya Tanaman Sawi «Cahaya Tani.htm. Diakses pada tanggal 8 Maret 2020.

Misbahuddin. 2011. Pupuk Cair. http:// www. permakulturaceh.org/kompos-cair. Diakses tanggal 05 Maret 2020.

Permentan, 2011, Peraturan Menteri Pertanian Tentang Pupuk Organik, Pupuk Hayatidan Pembenah tanah, Peraturan Menteri Pertanian Nomor 70/Permentan/SR.140/10/2011, Jakarta.

Mandha, 2010. Sawi. http://Uncategorizedmandha.htm. Diakses pada tanggal 8 Maret 2020.

Purwowidodo. 1992. Telaah Kesuburan Tanah. Penerbit Angkasa. Bandung.

Tay, D.C.S., and H. Toxopeus. 1994. Brassica rapa L. cv. group Pakcoy, Plant Resources of SouthEast Asia and Vegetables 8. PROSEA Foundation. J. Agronomi p.130-134. In: Journal a. S. Siemonsma and K. Piluek (Eds.).

Siswadi dan Yuwono, T. 2013. Uji hasil tanaman sawi pada berbagai media tanam secara hidroponik. Jurnal Innofarm 1 (2): 44-50.

Sutanto, R. 2002. Pertanian Organik: Menuju Pertanian Alternatif dan Berkelanjutan. Kanisius. Yogyakarta.

Yudharta. 2010. Tanaman Sawi http://Tanaman Sawi « Community Aji Chrw-95\%.htm. Diakses pada tanggal 2 Maret 2020. 